\title{
Restoration applications of resource objective wildfires in western US forests: a status of knowledge review
}

\author{
David W. Huffman * (D), John Paul Roccaforte, Judith D. Springer and Joseph E. Crouse
}

\begin{abstract}
Background: Frequent-fire forests of the western United States have undergone remarkable changes in structure, composition, and function due to historical exclusion of naturally occurring fire. Mechanized tree thinning to reduce forest density and fuel loads tends to be expensive and cannot be effectively implemented across all lands, and there is increasing interest in managing naturally ignited wildfires for meeting forest restoration objectives. To investigate general effectiveness of resource objective $(\mathrm{RO})$ wildfires for restoring frequent-fire and associated forests of the western United States, we conducted a review of the related peer-reviewed literature.

Results: Formal analysis of ecological responses to RO fires is relatively recent, and 21 of the 37 papers (57\%) we reviewed were published between the years 2010 and 2018. We found 17 studies that investigated RO fire outcomes in Sierra Nevada forests, while other ecoregions that were represented in the literature included ArizonaNew Mexico Mountains, Middle Rockies-Blue Mountains, and the Colorado Plateau. Yosemite National Park was utilized in 14 of the studies we reviewed. We noted several ecoregions where frequent-fire forests occur, but for which published studies on RO fires are lacking. The main focus of research (14 studies) was related to RO fire effects on forest structure, and next in importance was research (12 studies) related to fire severity, extent, and type, with studies of understory vegetation responses and landscape-scale patterns or dynamics also prevalent. Research findings indicated that RO fires were effective for reducing tree density and fire behavior; however, densities often remained above known historical ranges of variation in several studies. Understory responses reported in the literature were mixed with respect to effects on abundance and species richness. Increases in invasive species abundance in areas of high burn severity were consistently reported. Research on landscape patterns indicated that $\mathrm{RO}$ fires can increase heterogeneity with respect to vegetation distribution.

Conclusion: RO fires can be generally effective for restoration of frequent-fire forests, particularly on landscapes with long histories of fire use and in areas of moderate burn severity. More research is needed to test fire outcomes against specific restoration targets, and additional studies are needed concerning important ecological processes and functions.
\end{abstract}

Keywords: fire research, frequent-fire forests, literature synthesis, managed wildfire, prescribed natural fires, wildland fire use

* Correspondence: David.Huffman@nau.edu

Ecological Restoration Institute, Northern Arizona University, P.O. Box 15017, Flagstaff, Arizona 86011-5017, USA

\section{Springer Open}

(c) The Author(s). 2020 Open Access This article is licensed under a Creative Commons Attribution 4.0 International License, which permits use, sharing, adaptation, distribution and reproduction in any medium or format, as long as you give appropriate credit to the original author(s) and the source, provide a link to the Creative Commons licence, and indicate if changes were made. The images or other third party material in this article are included in the article's Creative Commons licence, unless indicated otherwise in a credit line to the material. If material is not included in the article's Creative Commons licence and your intended use is not permitted by statutory regulation or exceeds the permitted use, you will need to obtain permission directly from the copyright holder. To view a copy of this licence, visit http://creativecommons.org/licenses/by/4.0/. 


\section{Resumen}

Antecedentes: Los bosques del oeste de los Estados Unidos sujetos a incendios frecuentes han experimentado cambios notables en estructura, composición y funciones, debido a la exclusión histórica de los fuegos que ocurrían naturalmente. El raleo mecánico para reducir la densidad forestal y la carga de combustibles tiende a ser costoso y no puede ser aplicado eficientemente en todos los terrenos, por lo que hay un creciente interés en manejar fuegos iniciados naturalmente para lograr objetivos de restauración del bosque. Para investigar la efectividad general de los fuegos como objetivo de manejo del recurso $(\mathrm{RO})$ para restaurar fuegos frecuentes en bosques asociados a ese disturbio en el oeste de los Estados Unidos, realizamos una revisión de bibliografía relacionada y que estuviese sujeta a evaluación por pares.

Resultados: El análisis formal de las respuestas ecológicas a fuegos como objetivo de manejo (RO) es relativamente reciente, y 21 (57\%) de los 37 artículos que analizamos fueron publicados entre los años 2010 y 2018. Encontramos 17 estudios que investigaron los resultados de fuegos RO en los bosques de la Sierra Nevada, mientras que otras ecoregiones que estuvieron representadas en la bibliografía incluyeron las Montañas de Arizona y Nuevo México, las Rocallosas Centrales y la Cordillera Azul, y la Meseta de Colorado. Notamos diferentes eco-regiones donde los fuegos de bosques son frecuentes, pero que carecen de estudios de RO. El principal foco de la investigación (14 estudios) estuvo relacionada con los efectos de los $\mathrm{RO}$ en la estructura forestal, y el siguiente en importancia fue la investigación (12 estudios) relacionada con la severidad, extensión, y tipo de incendio, con estudios también prevalentes de respuesta del sotobosque y patrones a escala de paisaje o de dinámica de la vegetación. Los resultados de las investigaciones indican que los fuegos RO fueron efectivos para reducir la densidad de árboles y el comportamiento del fuego; sin embargo y en varios estudios, las densidades frecuentemente permanecieron por encima de los valores conocidos de variación histórica. Las respuestas del sotobosque reportados en la literatura fueron mixtos con respecto a los efectos sobre la abundancia y riqueza de especies. Los incrementos en especies invasoras en áreas de severidad alta de fuegos fueron reportados consistentemente. La investigación en patrones del paisaje indicó que los fuegos RO pueden incrementar la heterogeneidad relacionada a la distribución de la vegetación.

Conclusión: Los fuegos como objetivo de manejo de recursos (fuegos $\mathrm{RO}$ ) pueden ser generalmente efectivos para restaurar bosques en los cuales éste es un disturbio frecuente, particularmente en paisajes con mucha historia de uso del fuego y en áreas quemadas con moderada severidad. Más investigaciones son necesarias para probar los resultados del fuego ante objetivos de restauración específicos, y estudios adicionales son necesarios en relación a otros importantes procesos y funciones ecológicas.

\section{Abbreviations}

HRV: Historical Range of Variation

RO: Resource Objective wildfires

\section{Introduction}

Interruption of historical fire regimes and decades of fire suppression during the twentieth century were primary factors leading to major shifts in structure, composition, and function of dry forest ecosystems in the western United States (Covington et al. 1994; Allen et al. 2002; Hessburg et al. 2019). In many frequent-fire forests, lack of surface fire at frequent intervals allowed tree regeneration to proceed at rates much higher than indicated for historical forests. In more mesic systems, shifts in tree composition toward fire-intolerant and shade-tolerant species resulting from fire exclusion have also been widely reported (Schmidt et al. 2006; Hagmann et al. 2013; Strahan et al. 2016). Changes related to tree population irruptions have included increases in hazardous fuels and uncharacteristic fire behavior, reduced understory diver- sity, and homogenization of stand and landscape heterogeneity (Covington et al. 1994; Hessburg et al. 2019). Concern over these changes has motivated a series of natural resource policy mandates aimed at expanding and accelerating ecosystem restoration on public lands (Schoennagel et al. 2009; Franklin and Johnson 2012; Schultz et al. 2012; Stephens et al. 2016). It is widely understood that the combination of tree thinning using machinery or by handfelling, with reintroduction of controlled, low-intensity fire, is effective for meeting structural and functional restoration objectives, at least at small scales, in Western frequent-fire forests (Fulé et al. 2012; McIver et al. 2013; Sánchez Meador et al. 2017; Roccaforte et al. 2018). However, thinning treatments are often expensive, particularly in regions where restoration treatments focus on the removal of small, low-value trees (Hjerpe et al. 2009; Nicholls et al. 2018). Further, mechanized thinning may be infeasible for large and remote landscapes (North et al. 2015). In response to these limitations, there is increasing interest in managing wildfires that initiate from natural ignitions to achieve restoration objectives at multiple scales. 
Fire has long been recognized as a critical process in many forest ecosystems, and reintroduction of fire, with attention to natural fire regime characteristics, is a critical step in ecological restoration (Arno and Fiedler 2005). Ecological roles of fire include regulating tree regeneration and influencing stand dynamics, consuming fuel and modifying subsequent fire effects, driving understory vegetation dynamics and species composition, stimulating regeneration of sprouting species and those with dormant seed strategies, and creating landscape mosaics through variability in fire behavior and tree mortality (Whelan 1995). As early as 1968, wildfires have been allowed to burn and play their natural role in some remote areas of US National Park Service lands and, soon after, in US Forest Service wilderness areas (van Wagtendonk 2007). Wildfire may also serve as a restoration treatment to reverse ecological degradation following many years of fire exclusion (Huffman et al. 2017). In 2009, the Federal Wildland Fire Policy expanded the role of wildland fire use to explicitly include fuels management as well as several other resource management objectives, and shifted the application of wildfire use from areas set aside for ecosystem preservation to areas managed for multiple uses (Miller and Landres 2004). "Let burn," the original term for resource objective fires, was later modified to a variety of terms including "prescribed natural fire," "wildland fire use" (WFU), or "managed fire," and sometimes referred to as "restoration wildfire" (Hunter 2007; Barros et al. 2018). Today, these fires are often managed for multiple objectives, including resource objectives. For the purposes of our study, we use "resource objective" (hereafter, RO) wildfire. RO wildfires may help restore degraded forests by reducing tree densities, fuel loading, and potential for uncharacteristic crown fire; increasing understory abundance and species richness; and reestablishing landscape conditions more resilient to disturbances such as fire, insects, and drought. Restoration effectiveness may be evaluated by comparing wildfire outcomes with reference information from intact sites or historical ranges of variation (HRV) compiled from historical data or reconstructions (White and Walker 1997; Landres et al. 1999; Romme et al. 2012). In contrast, wildfires that result in large areas of high-severity burning or loss of key structures such as old trees, large snags, or logs, or fires that encourage increases in invasive, nonnative species are likely to conflict with goals for restoration of frequent-fire forests (Noss et al. 2006; Kolb et al. 2007; Waltz et al. 2014).

To date, there has been no systematic review of peerreviewed literature to evaluate $\mathrm{RO}$ wildfire effectiveness for accomplishing restoration objectives. Further, research needs for utilizing wildfire for restoration of frequent-fire forests of the western US have not been clearly articulated. The objectives of our analysis were to review the available peer-reviewed literature and address the following questions: (1) what are the basic demographics of the available literature including publication trends, location of studies, forest types, and research focus?; (2) what are the primary findings related to effectiveness for restoration of frequent-fire forests of the western United States?; and, (3) what science is still needed to address effectiveness of $\mathrm{RO}$ wildfires from an ecological restoration perspective?

\section{Methods \\ Database search}

To address our research questions, we conducted an evidence-based review of articles published in peerreviewed journals. We systematically searched bibliographic databases and compiled the relevant literature related to wildfires utilized to meet ecological restoration, fuels reduction, and ecosystem management (e.g., natural disturbance process) objectives. Our search encompassed CAB Abstracts (https://www.cabdirect.org/ cabdirect), BIOSIS (https://www.ebsco.com/), Web of Science (http://www.webofknowledge.com/), GreenFILE (https://www.ebsco.com/), and the Agricultural and Environmental Science Database (https://about.proquest. $\mathrm{com} /$ ). We used search strategies that combined terms commonly used to describe wildfires managed to achieve resource objectives with keywords that delineate major frequent-fire forests of the western US. We used the following search strategy, with syntax depending on database: [resource objective OR resource objectives OR resource benefit OR resource benefits OR naturally ignited $O R$ natural ignition $O R$ naturally ignite $O R$ lightning AND fire OR wildfire AND mixed conifer OR mixed-conifer OR pinyon juniper OR pinyon-juniper OR ponderosa pine OR pinus ponderosa OR jeffrey pine OR pinyon OR juniper OR pinus jeffreyi OR pinus edulis OR juniperus OR pinon OR WFU OR fire use OR managed wildfire OR managed wildfires OR natural fire OR natural fires OR natural wildfire OR natural wildfires]. Our initial search returned 289 articles, and this number was then reduced to 120 articles after we examined titles for relevance. Articles that we accepted into the final set for review needed to represent original research that analyzed ecological responses to resource objective wildfires. Abstracts and body text were evaluated to determine whether papers met these criteria. In addition, published papers that did not appear in the database searches, but were known by our team or identified during analysis, were included if they met our criteria. We did not review papers that solely considered unwanted wildfires that had elicited a suppression response from land managers, nor did we include studies solely focused on human-ignited, prescribed fire. Lastly, our interests were mainly in wildfire utilized for 
ecological restoration; therefore, we did not include studies that solely focused on mesic forest types with infrequent, stand-replacing fire regimes. We limited our review to peer-reviewed journal articles, since these are typically considered to be the highest quality sources of science information in terms of accuracy and reliability (Esch et al. 2018). The final set of papers we reviewed comprised 37 peer-reviewed articles published in scientific journals through the year 2018.

\section{Data extraction and analysis}

Data and information extracted from the 37 selected articles included basic bibliographic specifics (e.g., author names, publication year, title, and journal), study location and focal forest type or types, methods and analytical approaches, research findings, and author interpretations of results. We compiled the extracted information in a master spreadsheet to allow for categorization, sorting, and synthesis of details to address on our main research questions. To investigate our primary research questions, we chose to use simple counts of basic demographic characteristics of the literature such as publication rate, ecoregions within which studies were conducted, forest type, and research focus. We used a broad classification and descriptions published by The Nature Conservancy (http:// maps.tnc.org/gis_data.html) to identify ecoregions. Because we were interested in a broad synthesis of current state of knowledge, and due to variability in methodologies and metrics across studies included in the review, we did not pursue meta-analysis; however, we identified and tallied directional responses of attributes commonly used to evaluate restoration success in frequent-fire forests of the western US. In addition, we expected studies of wildfire effects to be primarily retrospective and observational, so we did not attempt to evaluate scientific rigor or rank science quality.

\section{Results and Discussion Literature demographics}

Although public land managers have allowed lightningignited wildfires to play their natural role in large national parks and wilderness areas beginning in the 1960s (National Park Service) and 1970s (US Forest Service), research on ecological responses to these events has only recently been pursued. For example, out of the 37 papers we reviewed, $57 \%$ were published between the years 2010 and 2018, and 38\% were published between 2000 and 2009 (Fig. 1a). Only two published studies examined ecological outcomes of RO fires between 1970 and 2000. This recent increase in research effort likely reflects a growth in awareness concerning ecological changes that have resulted from anthropogenic fire exclusion in fireprone ecosystems, the corresponding need for ecological restoration and fuels reduction in these forests, and interest in using wildfire to meet targeted resource objectives. During this period (2000 to 2018), several major policies and programs were enacted, including the Healthy Forest Restoration Act, the Collaborative Forest Landscape Restoration Act, Guidance of Federal Wildland Fire Management Policy, and the National Cohesive Wildland Fire Management Strategy (Steen-Adams et al. 2017). We also recognize that some earlier research on RO fires was published in "gray" literature sources (e.g., general technical reports, government documents, conference proceedings, etc.). Although gray literature varies in terms of scientific rigor, some of these earlier studies could have provided additional, useful information not examined here.

Seventeen of the 37 studies we reviewed investigated RO fire outcomes in Sierra Nevada forests in California (Fig. 2). Other ecoregions that were less well represented in the literature included Arizona-New Mexico Mountains (seven studies), the Middle Rockies-Blue Mountains (six studies), and the Colorado Plateau (four studies). A smaller number of RO fire studies were conducted in the Canadian Rocky Mountains (two studies) and Apache Highlands in Arizona (one study) ecoregions (Fig. 2). Thirty-one of the 37 studies were conducted in national parks or wilderness areas and 11 studies included or were focused on multiuse lands (Fig. 1b). Yosemite National Park was utilized in 14 of the studies we reviewed. These patterns parallel wildfire policy history and development of modern fire landscapes. For example, the National Park Service implemented policy to allow wildfires to burn in 1968, and the first parks to establish "let-burn zones" were Sequoia and Kings Canyon National Parks in the Sierra Nevada range (see van Wagtendonk 2007). Following this, Saguaro National Park (formerly Saguaro National Monument) in the Apache Highlands ecoregion began allowing "natural prescribed fires" to burn in 1971, and Yosemite implemented a wildland fire use program in 1972. Similarly, the US Forest Service began allowing wildfires to burn wilderness areas, the first being within the Selway-Bitterroot Wilderness in Idaho (Middle Rockies-Blue Mountains ecoregion) and the Gila Wilderness in New Mexico (Arizona-New Mexico Mountains ecoregion).

As we were interested in restoration applications of RO fires and purposely restricted our review to frequent-fire forest types, it was not surprising that 28 of the total 37 studies we reviewed were conducted in ponderosa pine (Pinus ponderosa P. Lawson \& C. Lawson) or Jeffrey pine (Pinus jeffreyi Murray) forests, and similarly 28 of the studies were conducted in dry mixedconifer forests. Several studies examined fire landscapes where more than one forest type was present. A smaller number of the total studies (14) examined ecological responses in mesic mixed-conifer or lower-elevation pinyon-juniper woodlands (5 studies; Fig. 1c). 

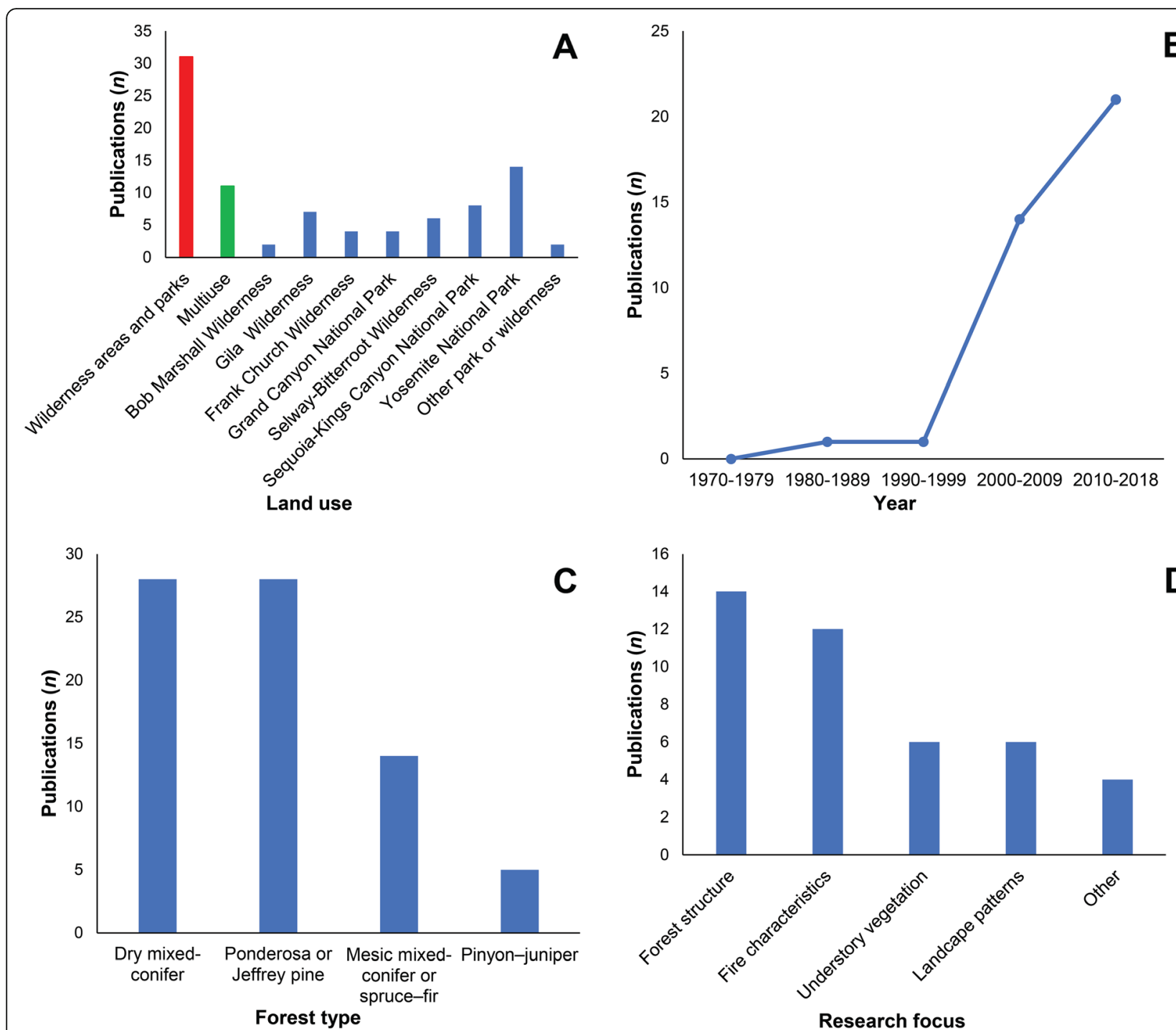

Fig. 1 Key demographic characteristics of peer-reviewed studies published through 2018 that were used to evaluate effectiveness of resource objective wildfires for restoring frequent-fire forests of the western US. Figure shows (A) publication rate, (B) classification of land use as well as national parks and wilderness areas that were prominent in published studies, (C) forest types within which studies were conducted, and (D) main research focus of published studies

Fourteen studies were related to effects of RO fires on forest structure, although studies reviewed were not wholly exclusive in their objectives and some investigated multiple topics (Fig. 1d). Next in prominence as a research topic were studies of fire type (12 studies; e.g., crown fire or surface fire), size, or severity. We found six studies investigating RO fire effects on understory vegetation, and six studies addressed landscape-scale patterns or dynamics. We found few other topics of research in the literature; one paper examined water resources and forest resiliency (Boisramé et al. 2017b), one studied fire effects on soils (DeLuca and Sala 2006), and another examined small mammal responses to RO fires (Roberts et al. 2015).

\section{Research findings}

\section{Forest structure}

The 14 studies of forest structure (Table 1) mostly focused on tree density, mortality across diameter classes, and impacts on species composition. Relatively few studies examined RO fire effects on hazardous fuels. Most studies utilized unburned areas for comparison, while a limited number of studies compared structural outcomes to HRV. Results on responses of important fine-scale structural attributes such as tree spatial patterns, snags, and "large" trees were not widely reported. Restorative effects in terms of reducing tree density were particularly pronounced in areas where wildfires had burned repeatedly, such as in parks and wilderness areas with long- 

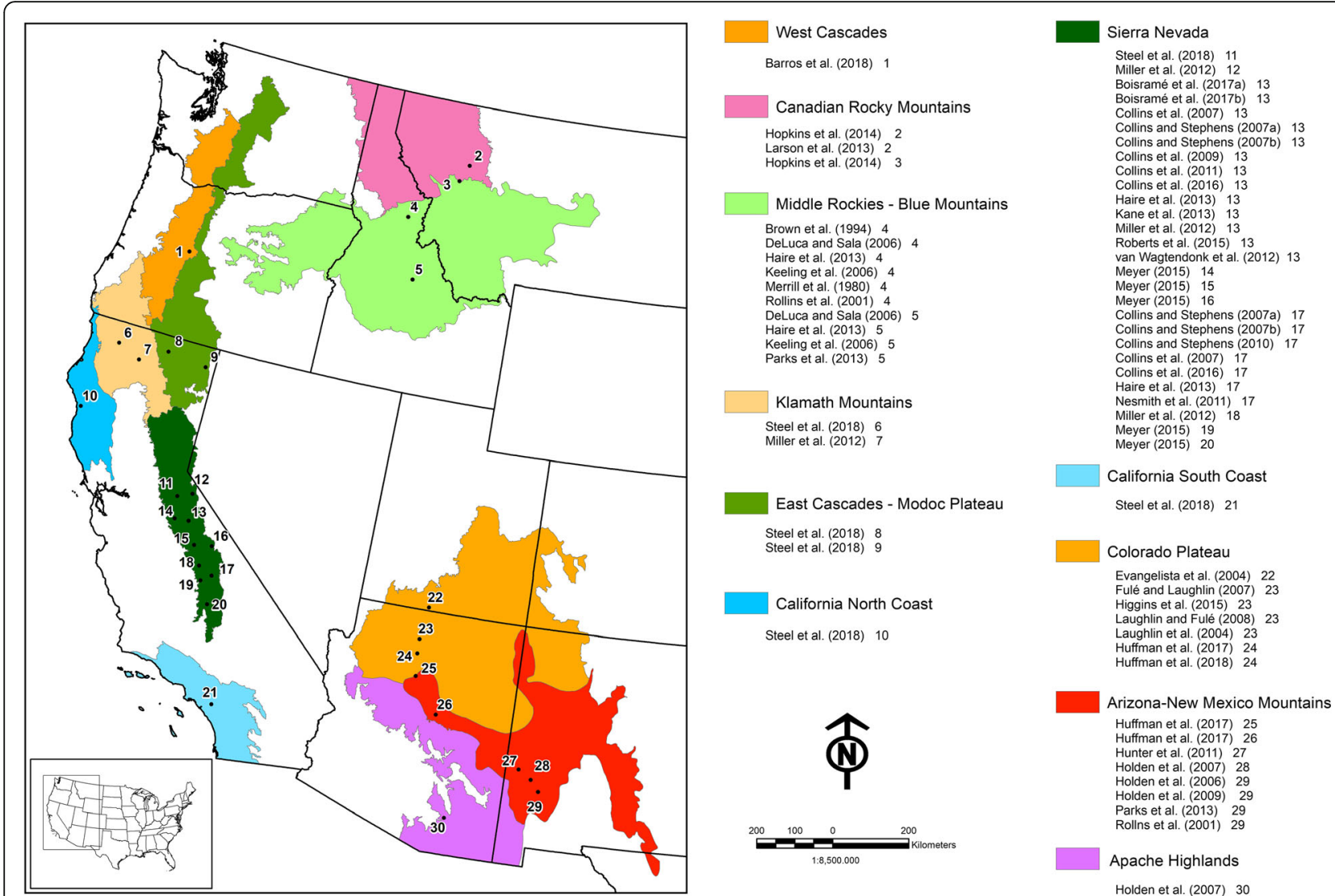

Fig. 2 Ecoregions (http://maps.tnc.org/gis_data.html) and locations of peer-reviewed studies published through 2018 that were used to evaluate effectiveness of resource objective wildfires for restoring frequent-fire forests of the western US

standing RO fire policies. Nearly all studies reporting on tree density changes indicated that effects aligned with ecological restoration objectives (Table 2).

In ponderosa pine forests of the Saguaro Wilderness in Arizona (now within Saguaro National Park) and the Gila Wilderness in New Mexico, Holden et al. (2007) found significantly lower tree density and fewer smalldiameter trees in burned versus unburned areas. In forests experiencing two or more fires, densities ranged from 376 to 540 trees ha $^{-1}$ (Holden et al. 2007), although HRV for Southwestern ponderosa pine forests typically ranged from 56 to 138 trees $\mathrm{ha}^{-1}$ prior to anthropogenic fire exclusion (Reynolds et al. 2013). Large ( $>45 \mathrm{~cm}$ diameter at breast height [dbh; $1.37 \mathrm{~m}$ above ground]) tree density was not statistically different between unburned and RO fire areas (Holden et al. 2007). Hunter et al. (2011) also found significantly lower tree densities and canopy fuels in RO fires compared with unburned areas on the Gila National Forest outside of the Gila Wilderness in New Mexico. In ponderosa pine forests experiencing two or three fires, tree densities ranged from 310 to 337 trees $\mathrm{ha}^{-1}$ and remained above HRV. Huffman et al. (2017) examined an array of structural variables and found that, after first-entry RO fires on multiuse US Forest Service lands in northern Arizona ponderosa pine, density approached HRV (172 \pm 97.1 trees $\mathrm{ha}^{-1}, 95 \% \mathrm{CI}$ ) only in areas classified as moderate burn severity. Relative numbers of large $(>40$ $\mathrm{cm} \mathrm{dbh}$ ) trees were deficient in other burn severity classes except moderate severity, but effects on absolute densities of large trees were not reported (Huffman et al. 2017). Huffman et al. (2018) reported that RO fires managed for low-severity burning resulted in few significant structural differences between first-entry and secondentry wildfires, and ponderosa pine tree densities (440.2 to 480.5 trees $\mathrm{ha}^{-1}$ ) remained above HRV.

In mixed-conifer forests, Fulé and Laughlin (2007) found that a single RO fire in Grand Canyon National Park in Arizona reduced small-diameter trees by 75 to 95\% and moved mid- and high-elevation forests toward historical conditions. Much of this mortality was experienced by shade-tolerant conifers, many of which had likely established as a result of anthropogenic fire exclusion, and large-tree $(>37.5 \mathrm{~cm} \mathrm{dbh})$ mortality ranged from 7 to $29 \%$ across all fires and species. Higgins et al. (2015) also found that small-diameter white fir (Abies 
Table 1 Peer-reviewed studies published through 2018 used to evaluate effectiveness of resource objective wildfires for restoring frequent-fire forests of the western US. Show are publication reference, ecoregion* (http://maps.tnc.org/gis_data.html), forest type ${ }^{\dagger}$, main research focus of study, and comparator ${ }^{\dagger+}$ used in each study

\begin{tabular}{|c|c|c|c|c|}
\hline Publication & Ecoregion* & Forest type $^{+}$ & Main focus & Comparator $^{+\dagger}$ \\
\hline Barros et al. 2018 & WC & PJ, PP/JP, DMC, MMC & Landscape modeling & High-risk fires \\
\hline Boisramé et al. 2017a & SN & DMC, MMC & Landscape structure & $\begin{array}{l}\text { Fire suppression; } \\
\text { repeated fires }\end{array}$ \\
\hline Boisramé et al. 2017b & SN & DMC & Landscape structure, water resources & Unburned sites \\
\hline Brown et al. 1994 & MRBM & $\mathrm{PP} / \mathrm{JP}, \mathrm{DMC}, \mathrm{MMC}$ & Fire characteristics & Presettlement fires \\
\hline Collins and Stephens 2007a & SN & $\mathrm{PP} / \mathrm{JP}, \mathrm{DMC}, \mathrm{MMC}$ & Fire characteristics & Historical fire regime \\
\hline Collins and Stephens 2007b & SN & $\mathrm{PP} / \mathrm{JP}, \mathrm{DMC}, \mathrm{MMC}$ & Tree scarring & Fire atlases \\
\hline Collins and Stephens 2010 & SN & $\mathrm{PP} / \mathrm{JP}, \mathrm{DMC}, \mathrm{MMC}$ & Fire characteristics & none \\
\hline Collins et al. 2007 & SN & $\mathrm{PP} / \mathrm{JP}, \mathrm{DMC}$ & Fire characteristics & Alternate $\mathrm{RO}$ fires \\
\hline Collins et al. 2009 & SN & $\mathrm{PP} / \mathrm{JP}, \mathrm{DMC}, \mathrm{MMC}$ & Fire characteristics & $\mathrm{RO}$ fire periods \\
\hline Collins et al. 2011 & SN & $\mathrm{PP} / \mathrm{JP}, \mathrm{DMC}$ & Forest structure & Unburned; historical \\
\hline Collins et al. 2016 & SN & $\mathrm{PP} / \mathrm{JP}, \mathrm{DMC}, \mathrm{MMC}$ & Forest structure, landscape variability & none \\
\hline DeLuca and Sala 2006 & MRBM & DMC & Soil nutrients & Fire-excluded \\
\hline Evangelista et al. 2004 & $\mathrm{CP}$ & PJ & Understory vegetation & Unburned sites \\
\hline Fulé and Laughlin 2007 & $\mathrm{CP}$ & $\mathrm{PP} / \mathrm{JP}, \mathrm{DMC}$ & Forest structure & Prefire and unburned \\
\hline Haire et al. 2013 & SN, MRBM, ANMM & PJ, PP/JP, DMC, MMC & Fire characteristics & Wilderness status \\
\hline Higgins et al. 2015 & $\mathrm{CP}$ & $\mathrm{PP} / \mathrm{JP}, \mathrm{DMC}$ & Forest structure & Unburned sites \\
\hline Holden et al. 2006 & ANMM & $\mathrm{PP} / \mathrm{JP}$ & Forest structure & Repeated fires \\
\hline Holden et al. 2007 & ANMM, AH & PJ, PP/JP, DMC, MMC & Forest structure & Unburned sites \\
\hline Holden et al. 2009 & ANMM & $\mathrm{PP} / \mathrm{JP}, \mathrm{DMC}$ & Fire characteristics & Topography \\
\hline Hopkins et al. 2014 & $C R$ & Other & Forest structure & Restoration treatments \\
\hline Huffman et al. 2017 & CP, ANMM & $\mathrm{PP} / \mathrm{JP}$ & Forest structure & HRV \\
\hline Huffman et al. 2018 & $\mathrm{CP}$ & $\mathrm{PP} / \mathrm{JP}$ & Forest structure & Repeated fires \\
\hline Hunter et al. 2011 & ANMM & $\mathrm{PP} / \mathrm{JP}, \mathrm{DMC}$ & $\begin{array}{l}\text { Forest structure, understory vegetation, } \\
\text { characteristics }\end{array}$ & $\begin{array}{l}\text { Rx; unburned; repeated } \\
\text { fires }\end{array}$ \\
\hline Kane et al. 2013 & SN & $\mathrm{PP} / \mathrm{JP}$ & Landscape structure & Unburned sites \\
\hline Keeling et al. 2006 & MRBM & $\mathrm{PP} / \mathrm{JP}, \mathrm{DMC}, \mathrm{MMC}$ & Understory vegetation, forest structure & Unburned sites \\
\hline Larson et al. 2013 & $C R$ & $\mathrm{PP} / \mathrm{JP}$ & Forest structure & Repeated fires \\
\hline Laughlin and Fulé 2008 & $\mathrm{CP}$ & $\mathrm{PP} / \mathrm{JP}, \mathrm{DMC}, \mathrm{MMC}$ & Understory vegetation & $\begin{array}{l}\text { Prefire and unburned } \\
\text { sites }\end{array}$ \\
\hline Laughlin et al. 2004 & $\mathrm{CP}$ & $\mathrm{PP} / \mathrm{JP}$ & Understory vegetation & Reference sites \\
\hline Merrill et al. 1980 & MRBM & $\mathrm{PP} / \mathrm{JP}$ & Understory vegetation & Unburned sites \\
\hline Meyer 2015 & SN & $\mathrm{PP} / \mathrm{JP}, \mathrm{DMC}$ & Fire characteristics & HRV \\
\hline Miller et al. 2012 & SN, KM & $\mathrm{PP} / \mathrm{JP}, \mathrm{DMC}$ & Fire characteristics & $\begin{array}{l}\text { Ecoregions; agencies; } \\
\text { wilderness status; } \\
\text { forest type }\end{array}$ \\
\hline Nesmith et al. 2011 & SN & $\mathrm{DMC}$ & Forest structure & $\mathrm{Rx}$ \\
\hline Parks et al. 2014 & MRBM, ANMM & $P J, P P / J P, D M C, M M C$ & Fire characteristics & Repeated fires \\
\hline Roberts et al. 2015 & SN & DMC & Small mammals & Unburned sites \\
\hline Rollins et al. 2001 & MRBM, ANMM & DMC, MMC, Other & Fire characteristics & Fire eras \\
\hline Steel et al. 2018 & $\mathrm{KM}, \mathrm{CNC}, \mathrm{ECMP}, \mathrm{CSC}, \mathrm{SN}$ & $\mathrm{PP} / \mathrm{JP}, \mathrm{DMC}$ & Landscape structure & Fire suppression \\
\hline van Wagtendonk et al. 2012 & SN & $\mathrm{DMC}$ & Fire characteristics & Repeated fires \\
\hline
\end{tabular}

${ }^{*}$ Ecoregion: $\mathrm{AH}=$ Apace Highlands; $\mathrm{ANMM}=$ Arizona-New Mexico Mountains; $\mathrm{CNC}=$ California North Coast; $\mathrm{CP}=\mathrm{Colorado}$ Plateau; $\mathrm{CRM}=\mathrm{Canadian}$ Rocky Mountains; CSC = California South Coast; ECMP = East Cascades-Modoc Plateau; KM = Klamath Mountains; MRBM = Middle Rockies-Blue Mountains; $\mathrm{SN}=$ Sierra Nevada; $\mathrm{WC}=$ West Cascades

${ }^{+}$Forest type codes: $\mathrm{PJ}=$ pinyon-juniper; $\mathrm{PP} / \mathrm{JP}=$ ponderosa pine-Jeffrey pine; $\mathrm{DMC}=$ dry mixed-conifer; $\mathrm{MMC}=$ mesic mixed-conifer

${ }^{\mathrm{Ht}} \mathrm{Rx}=$ prescribed fire; $\mathrm{HRV}=$ historical range of variation 
Table 2 Peer-reviewed studies published through 2018 were used to evaluate effectiveness of resource objective wildfires for restoring frequent-fire forests of the western US. Table shows the number of publications reporting decreases, neutral (no change), or increases in attributes commonly used to evaluate ecological restoration success in frequent-fire forests of the western United States. Bolded responses are typically considered desirable restoration outcomes (e.9., Reynolds et al. 2013). Note: attributes are not mutually exclusive to individual studies; some publications reported on responses of multiple attributes

\begin{tabular}{lccr}
\hline & Response & & \\
\cline { 2 - 4 } Attribute & Decrease & Neutral & Increase \\
\hline Forest structure & $\mathbf{1 0}$ & 0 & 0 \\
Total tree density & $\mathbf{6}$ & 0 & 0 \\
Fire-intolerant species density & $\mathbf{6}$ & 0 & 0 \\
Small-diameter tree density & 3 & 2 & 0 \\
Large-diameter tree density & & & \\
Fire characteristics & $\mathbf{4}$ & 2 & 1 \\
Burn severity & $\mathbf{3}$ & 0 & 0 \\
Fire extent or size & & & \\
Understory vegetation & 1 & 3 & $\mathbf{2}$ \\
Total abundance & 1 & 2 & $\mathbf{2}$ \\
Species richness & 0 & 1 & 3 \\
Exotic species abundance & & & \\
Landscape patterns & & 0 & $\mathbf{5}$ \\
Heterogeneity & & 0 & $\mathbf{4}$ \\
Stability or resilience & & &
\end{tabular}

concolor [Gord. \& Glend.] Lindl. ex Hildebr.) density was significantly lower on unburned plots $\left(28\right.$ trees ha $\left.^{-1}\right)$ than on plots burned by two RO fires $\left(113\right.$ trees $\left.\mathrm{ha}^{-1}\right)$ in dry mixed-conifer forests of Grand Canyon National Park. Larson et al. (2013) concluded that repeated wildfires could restore forest structure in dry mixed-conifer forests of the Bob Marshall Wilderness in Montana by reducing numbers of smaller Douglas-fir (Pseudotsuga menziesii [Mirbel] Franco) and lodgepole pine (Pinus contorta Douglas ex Loudon) without negatively affecting more fire-resilient ponderosa pine, but single fires may move these ecosystems along alternative trajectories due to initial inputs of coarse wood and unchecked lodgepole pine regeneration. After two RO fires, mortality of small trees $(<40 \mathrm{~cm} \mathrm{dbh})$ tended to be greater than that of larger trees $(>40$ to $120 \mathrm{~cm} \mathrm{dbh}$ ) for all species combined. In Yosemite and Sequoia and Kings Canyon national parks in California, Collins and Stephens (2007a) found that trees established following fire exclusion remained alive even after several decades of wildfire use. Collins et al. (2011) compared historic (1911) timber inventories to contemporary (2005 to 2007) conditions within dry mixed-conifer forests of Yosemite National Park and reported that contemporary tree densities were significantly greater than historic inventories except in RO fire areas classified as moderate burn severity.

\section{Fire characteristics}

Common variables of interest in the 12 studies of fire characteristics (Table 1) included fire type, size, and severity. Similar to studies of structure, most comparisons of $\mathrm{RO}$ fire outcomes were compared against unburned sites, but a smaller number of studies compared RO fires to historical regimes. Most studies examining changes to fire characteristics showed desirable outcomes of $\mathrm{RO}$ fires, particularly with respect to decreases in subsequent burn severity and fire size (Table 2). For example, Hunter et al. (2011) reported that fire type was predicted to be surface fire or passive crown fire at sites burned by RO fires, whereas unburned areas were predicted to show active crown fire in ponderosa pine forests of New Mexico. In the Gila Wilderness in New Mexico, Rollins et al. (2001) found that mean and maximum fire sizes (fire area) were larger during the recent fire-use period (1975 to 1993) compared with fires prior to EuroAmerican settlement ("presettlement"). This was likely related to changes in fuels and forest structure that arose during the pre-modern suppression period (1909 to 1946). Parks et al. (2014) found that previous fires moderated burn severity of subsequent fires, likely through consumption of fuel, and areas with repeated fire in the Gila Wilderness experienced lower burn severity than those that had no other recent fires. High-severity fire in the Gila Wilderness tended to occur more frequently on more mesic, cooler, north-facing sites (Holden et al. 2009). Haire et al. (2013) found similar results in Southwestern wilderness areas where landscape heterogeneity resulting from fire use moderated the role of large fires, but this pattern was not observed in the Sierra Nevada range or Northern Rockies. Huffman et al. (2018) reported no significant differences in active crown fire percentage between first- and second-entry $\mathrm{RO}$ fires, a result probably related to mild weather conditions and low-severity burning in these fires on multiuse, nonwilderness lands.

In Yosemite National Park, Collins et al. (2009) reported that fire landscapes can reach a self-regulating condition in which fire extent and severity is moderated by previous fires; however, this effect can be negated with increasing time since last fire and fire weather. Similarly, van Wagtendonk et al. (2012) found that fire severity in the same Yosemite National Park area studied by Collins et al. (2009) was related to time since last fire, number of fires, weather, and vegetation type. In another study, Collins and Stephens (2010) reported that stand- 
replacing fire patch sizes were related to vegetation, whereas smaller patches were associated with shruband pine-dominated vegetation and larger patches were more common in shade-tolerant and fir-dominated forests. Miller et al. (2012) concluded that, due to differences in fire-use policies and history, fires in Yosemite National Park showed a lower percentage of highseverity burning, smaller high-severity patches, and smaller fire sizes than fires in non-wilderness areas on national forests of the Sierra Nevada region. Indeed, Collins and Stephens (2007a) found that RO fires in Yosemite and Sequoia and Kings Canyon national parks behaved similarly to those of the historical, pre-fireexclusion period in terms of frequency, effects, and extent, although trees established during the fire-exclusion period survived. In contrast, Brown et al. (1994) estimated that, for all fire regimes types in the SelwayBitterroot Wilderness in Montana, annual area burned by stand-replacing fire was 1.5 -fold greater during the pre-fire-exclusion period, and annual area burned by non-lethal "understory" fire was 1.9-fold greater during this period (determined from fire return interval samples), compared with annual area burned during the recent $\mathrm{RO}$ fire period (determined from total area of mapped fires averaged over the 12-year RO period). For lower-elevation fire regime types, presettlement to $\mathrm{RO}$ period ratios for annual area burned by stand-replacing and understory fire were 1.2 and 2.2, respectively. Interestingly, Meyer (2015) reported that RO fire severity proportions and high-severity patch sizes tended to be within HRV in four national forests of the southern Sierra Nevada range.

\section{Understory vegetation}

We found relatively few studies (6) focused on understory vegetation (Table 1), and RO fire effects on abundance and species richness varied (Table 2). Studies reporting on understory species composition changes consistently indicated increases in exotic species abundance after RO wildfires (Table 2). Laughlin et al. (2004) made use of repeated measurements before and after RO fires and compared a first-entry fire site to two reference sites with intact, frequent-fire regimes in ponderosa pine forests of Grand Canyon National Park. These authors found that the RO fire shifted species composition to greater similarity to the reference sites, but species richness, plant cover, and diversity at the RO site remained significantly lower than the reference sites (Laughlin et al. 2004). In another study at Grand Canyon National Park, Laughlin and Fulé (2008) showed minor increases in understory plant cover and species richness two years after a low-severity fire at a ponderosa pine reference site. Increase in graminoid richness was explained by occurrence of the invasive, exotic cheatgrass
(Bromus tectorum L.; Laughlin and Fulé 2008). In ponderosa pine forests of the Selway-Bitterroot Wilderness, Merrill et al. (1980) reported that herbaceous biomass in burned areas ranged from 1.3 to 1.6 times greater than in unburned areas over four years of monitoring. Cheatgrass showed 10 to $24 \%$ cover in burned areas over two years, whereas cover of this species in unburned areas was 6 to 9\% (Merrill et al. 1980). In contrast to these studies, Evangelista et al. (2004) found lower cover of vascular plants and biological soil crust, and lower native species richness on burned sites in comparison with unburned sites in juniper woodlands of Grand StaircaseEscalante National Monument in Utah. Nonnative species richness and cover were also higher on burned sites than unburned sites, although cheatgrass dominated both types of sites in this system (Evangelista et al. 2004). Based on parallel findings at ponderosa pineDouglas-fir sites in Selway-Bitterroot and Frank Church River of No Return (Idaho) wilderness areas, Keeling et al. (2006) suggested that site characteristics may be more important than fire exposure in driving species composition, and expectations of increasing understory richness with repeated fires may not hold over long time periods. Hunter et al. (2011) found no significant effects of RO fires on grass and forb cover as compared with unburned plots.

\section{Landscape patterns}

Similar to our findings for understory responses, studies of $\mathrm{RO}$ fire effects on landscape-scale changes were not plentiful in the literature $(n=6$; Table 1$)$. Studies we reviewed that examined RO fire effects on landscape patterns, mainly through comparisons with unburned sites, consistently showed increases in heterogeneity (Table 2). A small number of studies suggested that landscapes experiencing decades of fire use appeared stable in terms of burn severity and increases in heterogeneity conferred greater resiliency than fire-excluded landscapes (Table 2). Several authors suggested that $\mathrm{RO}$ landscapes could serve as references for restoration planning. For example, Collins et al. (2007) studied fires in Yosemite and Sequoia and Kings Canyon national parks and concluded that landscape heterogeneity, as measured by variation in forest type, increased as a result of areas burning at different severities, and over time these mosaics likely resembled natural patterns and could be used to guide restoration treatments on other landscapes. Kane et al. (2013) showed that trajectories of structural changes were related to burn severity and forest type, but highseverity fire tended to produce transitions to open, treeless patches in Yosemite National Park. Similarly, Collins et al. (2016) found that variation in vegetation structure in Yosemite National Park was influenced by site productivity and previous fire severity, and again suggested that RO fires, which have been allowed to burn in the Illilouette Creek 
Basin since 1972, have produced a reference landscape that could inform landscape-scale restoration planning elsewhere. Boisramé et al. (2017a) reported that four decades of Yosemite National Park fires had decreased forest cover and had increased vegetation heterogeneity within the Illilouette Creek Basin. Lower forest cover and greater heterogeneity at this study site wee associated with lower drought-related tree mortality than on adjacent fire-excluded watersheds (Boisramé et al. 2017b). Although Collins et al. (2009) concluded that free-burning fires in the Illilouette Creek Basin can be self-limiting in terms of severity and extent when weather conditions are not extreme and time since fire is less than nine years, Boisramé et al. (2017a) found that metrics describing landscape structure at the same site were not stable, which indicated continuing recovery from approximately 100 years of earlier fire exclusion.

\section{Synthesis and research needs}

Our review of published studies indicated that RO wildfires may be generally effective for restoring forest structure and fire characteristics in western US forests where historical fire exclusion has led to degraded conditions. However, studies focused on ecological restoration applications, and evaluation of RO wildfire effectiveness from a restoration perspective, are not numerous. Several research areas that would be productive for informing restoration were revealed in our review.

\section{Multiuse lands}

Relatively few published studies have been conducted outside national parks and wilderness areas, and although these studies have yielded important information, particularly with respect to development of fire landscapes, most were conducted after 2010 (Fig. 1). For locations such as Yosemite and Sequoia and Kings Canyon national parks, and Gila and Selway-Bitterroot wilderness areas, this is around three decades after initiation of fire-use policies. More research is needed to understand ecological responses to initial fire entry (e.g., first or second entry) and management approaches that help optimize effectiveness of these fires for restoration of forests on multiuse lands. On these lands, concern over fire escape and damage to various types of resources often forces managers to be more cautious with regard to when and where they allow fires to burn (Black et al. 2008). Present guidance allows for concurrent management of any given wildfire for various objectives, and objectives for a fire may change over time. Thus, to more clearly evaluate general effectiveness of wildfires for meeting restoration objectives, researchers must work closely with managers to better understand decisions and actions taken for each individual fire. Future research should examine forest responses and restoration benefits over time on multiuse landscapes where $\mathrm{RO}$ fires are repeatedly managed for low-severity burning.
Response variables of interest could include fuels dynamics and those that can be affected by forest density such as potential fire behavior and understory vegetation.

\section{Understudied ecoregions}

RO fire studies were predominantly located in ecoregions of California, particularly in the Sierra Nevada range, the northern Rocky Mountains, and the Southwest. Interestingly, we found a lack of published studies for some important ecoregions where frequent-fire ecosystems occur and where wildland fires are utilized for resource benefits. For example, LANDFIRE Fire Regime Groups maps (https://www.landfire.gov/) indicate frequent, low-severity fire, forest landscapes in Utah High Plateaus, Southern Rocky Mountains, Utah-Wyoming Rocky Mountains, Black Hills, and Okanagan ecoregions; however, we found no studies of RO fires in these ecoregions. Broader understanding of $\mathrm{RO}$ fire use for restoration of Western forests requires additional work in these understudied ecoregions.

\section{Fine-scale structural effects}

We found strong evidence that RO fires reduce tree density, ladder fuels (small trees), canopy fuels, and density of fire-intolerant species. Effects on tree density and species composition were related to burn severity and number of wildfire events. Several studies indicated that RO fires had minimal effects on large and old trees, but in areas where burn severity was high, loss of trees of all sizes often led to stable shrublands or meadows. More research and monitoring is needed to better understand burn severity thresholds at which stand density is reduced and composition is shifted toward fire-tolerant species without undesirable effects on large and old trees. Other understudied structural responses include tree spatial patterns, and effects on large log density and snags.

The limited number of studies we found related to $\mathrm{RO}$ fire effects on understory communities showed mixed results. Abundance and native species richness were found to show a range of responses from increases to decreases. Several studies indicated increases in nonnative species such as cheatgrass, especially in areas of high burn severity. These findings are not unexpected and similar patterns are reported in the broader literature related to wildfire effects on understory communities (Crawford et al. 2001; Floyd et al. 2006; Kuenzi et al. 2008). Although increasing understory diversity is often a restoration objective, responses to changes in tree density and fire can be complex and influenced by various factors including burn severity, soil conditions, climate variability, herbivory, and plant functional traits (Abella and Springer 2015). It has been suggested that community trait characteristics that confer resilience to 
anticipated environmental conditions and climate change may be better restoration targets than increases in overall plant abundance or species composition per se (Laughlin et al. 2017). Research analyzing RO fire effects on functional responses of understory communities would be productive.

\section{Restoration success}

In several studies, tree density remained above HRV even after repeated RO fires. Limited research suggested that moderate burn severity in first-entry fires can adequately reduce stand density and move forest conditions within HRV (Huffman et al. 2017). However, minor effects from low-severity burning, even after repeated fires, may not satisfactorily meet restoration objectives. These conclusions are difficult to reach in studies utilizing unburned sites as a sole comparator, or without interpretation that considers pre-fire-exclusion conditions or desired outcomes. More research is needed to evaluate RO fire effects against explicit and well-articulated restoration objectives.

We found strong evidence to indicate that $\mathrm{RO}$ fires may reduce subsequent fire size and severity, particularly as compared with areas that have experienced no recent fire. Studies indicated that effects were dependent on severity of previous fires, forest type, and time since last fire. Over time, areas with repeated RO fires may develop fire regime characteristics such as frequency, extent, and severity that are similar to HRV. However, results were mixed, and at least one study concluded that some landscapes historically experienced more area burned than that observed contemporarily. It should also be noted that fire size and burn severity alone may be poor indicators of restoration success. Rather than being closely related to fuel loading and forest structural conditions, low-severity fire may simply reflect mild weather conditions and high fuel moistures under which RO fires tend to be managed (Huffman et al. 2018).

On landscapes with longer histories of fire use, RO fires can increase landscape heterogeneity with respect to distribution of vegetation patches, and these changes were related to burn severity, forest or vegetation type, and physical setting. However, more research is needed to determine whether mosaics produced by wildfire events on landscapes altered by many years of fire exclusion resemble historical patterns, and how these patterns affect important ecological processes such as wildlife use and movement, resilience to climate change, and widespread disturbances such as insect outbreaks and drought. Further, landscapes experiencing a long period of fire use provide opportunities to test hypotheses regarding landscape dynamics and recovery from changes related to historical fire exclusion. It is presently unclear whether managers should consider such landscapes as reference sites for restoration planning, and more work could be done to compare patterns on fire-use landscapes with those where fire regimes have not been substantially disrupted. Lastly, our review identified research and monitoring gaps related to effects of $\mathrm{RO}$ fires and fire-use landscapes on wildlife habitat and ecological functions such as soils and hydrologic responses.

\section{Acknowledgments}

The authors wish to thank M. DeJong at Northern Arizona University (NAU), Cline Library, for assistance in literature searches. Two anonymous reviewers provided helpful comments on an earlier draft of this paper. This research was supported by a grant from the US Forest Service and by Arizona's Technology and Research Initiative Fund. NAU is an equal opportunity provider.

\section{Authors' contributions}

DWH led and designed the study, created graphs, interpreted results, and wrote the manuscript. JDS, JPR, and JEC conducted systematic searches of bibliographic databases and compiled relevant literature. JPR assisted with summarizing data for tables and figures and formatted the final manuscript. JEC created the study site map. All authors read, edited, and approved the final manuscript.

\section{Funding}

This research was funded by a grant from the USDA Forest Service.

\section{Availability of data and materials}

The datasets used and analyzed during the current study are available from the corresponding author on reasonable request.

Ethics approval and consent to participate

Not applicable.

\section{Consent for publication}

Not applicable.

\section{Competing interests}

The authors declare that they have no competing interests.

Received: 19 February 2020 Accepted: 26 June 2020

Published online: 23 July 2020

\section{References}

Abella, S.R., and J.D. Springer. 2015. Effects of tree cutting and fire on understory vegetation in mixed conifer forests. Forest Ecology and Management 335: 281-299 https://doi.org/10.1016/j.foreco.2014.09.009.

Allen, C.D., M. Savage, D.A. Falk, K.F. Suckling, T.W. Swetnam, T. Schulke, P.B. Stacey, P. Morgan, M. Hoffman, and J.T. Klingel. 2002. Ecological restoration of southwestern ponderosa pine ecosystems: a broad perspective. Ecological Applications 12 (5): 1418-1433 https://doi.org/10.1890/10510761(2002)012[1418:EROSPP]2.0.CO;2.

Arno, S.F., and C.E. Fiedler. 2005. Mimicking nature's fire - restoring fire-prone forests in the West. Washington D.C.: Island Press.

Barros, A.M.G., A.A. Ager, M.A. Day, M.A. Krawchuk, and T.A. Spies. 2018. Wildfires managed for restoration enhance ecological resilience. Ecosphere 9 (3): e02161 https://doi.org/10.1002/ecs2.2161.

Black, A., M. Williamson, and D. Doane. 2008. Wildland fire use barriers and facilitators. Fire Management Today 68 (1): 10-14.

Boisramé, G., S. Thompson, B. Collins, and S. Stephens. 2017b. Managed wildfire effects on forest resilience and water in the Sierra Nevada. Ecosystems 20 (4): 717-732 https://doi.org/10.1007/s10021-016-0048-1.

Boisramé, G.F.S., S.E. Thompson, M. Kelly, J. Cavalli, K.M. Wilkin, and S.L. Stephens. 2017a. Vegetation change during 40 years of repeated managed wildfires in the Sierra Nevada, California. Forest Ecology and Management 402: 241-252 https://doi.org/10.1016/j.foreco.2017.07.034.

Brown, J.K. S.F. Arno, S.W. Barrett, and J.P. Menakis. 1994. Comparing the prescribed natural fire program with presettlement fires in the Selway- 
Bitterroot Wilderness. International Journal of Wildland Fire 4 (3): 157-168 https://doi.org/10.1071/WF9940157.

Collins, B.M., R.G. Everett, and S.L. Stephens. 2011. Impacts of fire exclusion and recent managed fire on forest structure in old growth Sierra Nevada mixedconifer forests. Ecosphere 2 (4): 51 https://doi.org/10.1890/ES11-00026.1.

Collins, B.M., M. Kelly, J.W. van Wagtendonk, and S.L. Stephens. 2007. Spatial patterns of large natural fires in Sierra Nevada wilderness areas. Landscape Ecology 22: 545-557 https://doi.org/10.1007/s10980-006-9047-5.

Collins, B.M., J.M. Lydersen, D.L. Fry, K. Wilkin, T. Moody, and S.L. Stephens. 2016. Variability in vegetation and surface fuels across mixed-conifer-dominated landscapes with over 40 years of natural fire. Forest Ecology and Management 381: 74-83 https://doi.org/10.1016/j.foreco.2016.09.010.

Collins, B.M., J.D. Miller, A.E. Thode, M. Kelly, J.W. van Wagtendonk, and S.L. Stephens. 2009. Interactions among wildland fires in a long-established Sierra Nevada natural fire area. Ecosystems 12 (1): 114-128 https://doi.org/10.1007/s10021-0089211-7.

Collins, B.M., and S.L. Stephens. 2007a. Managing natural wildfires in Sierra Nevada wilderness areas. Frontiers in Ecology and the Environment 5 (10): 523-527 https://doi.org/10.1890/070007.

Collins, B.M., and S.L. Stephens. 2007b. Fire scarring patterns in Sierra Nevada wilderness areas burned by multiple wildland fire use fires. Fire Ecology 3 (2): 53-67 https://doi.org/10.4996/fireecology.0302053.

Collins, B.M., and S.L. Stephens. 2010. Stand-replacing patches within a 'mixed severity' fire regime: quantitative characterization using recent fires in a longestablished natural fire area. Landscape Ecology 25 (6): 927-939 https://doi. org/10.1007/s10980-010-9470-5.

Covington, W.W., R.L. Everett, R. Steele, L.L. Irwin, T.A. Daer, and A.N.D. Auclair. 1994. Historical and anticipated changes in forest ecosystems of the Inland West of the United States. Journal of Sustainable Forestry 2 (1-2): 13-63 https://doi.org/10.1300/J091v02n01_02.

Crawford, J.A., C.-H.A. Wahren, S. Kyle, and W.H. Moir. 2001. Responses of exotic plant species to fires in Pinus ponderosa forests in northern Arizona. Journal of Vegetation Science 12 (2): 261-268 https://doi.org/10.2307/3236610.

DeLuca, T.H., and A. Sala. 2006. Frequent fire alters nitrogen transformations in ponderosa pine stands of the Inland Northwest. Ecology 87 (10): 2511-2522 https://doi.org/10.1890/0012-9658(2006)87[2511:FFANTI]2.0.CO;2.

Esch, B.E., A.E.M. Waltz, T.N. Wasserman, and E.L. Kalies. 2018. Using best available science information: determining best and available. Journal of Forestry 116 (5): 473-480 https://doi.org/10.1093/jofore/fvy037.

Evangelista, P., T.J. Stohlgren, D. Guenther, and S. Stewart. 2004. Vegetation response to fire and postburn seeding treatments in juniper woodlands of the Grand Staircase-Escalante National Monument, Utah. Western North American Naturalist 64 (3): 293-305 https://www.jstor.org/stable/41717377.

Floyd, M.L., D. Hanna, W.H. Romme, and T.E. Crews. 2006. Predicting and mitigating weed invasions to restore natural post-fire succession in Mesa Verde National Park, Colorado, USA. International Journal of Wildland Fire 15 (2): 247-259 https://doi.org/10.1071/WF05066.

Franklin, J.F., and K.N. Johnson. 2012. A restoration framework for federal forests in the Pacific Northwest. Journal of Forestry 110 (8): 429-439 https://doi.org/ 10.5849/jof.10-006.

Fulé, P.Z., J.E. Crouse, J.P. Roccaforte, and E.L. Kalies. 2012. Do thinning and/or burning treatments in western USA ponderosa or Jeffrey pine-dominated forests help restore natural fire behavior? Forest Ecology and Management 269: 68-81 https://doi.org/10.1016/j.foreco.2011.12.025.

Fulé, P.Z., and D.C. Laughlin. 2007. Wildland fire effects on forest structure over an altitudinal gradient, Grand Canyon National Park, USA. Journal of Applied Ecology 44: 136-146 https://doi.org/10.1111/j.1365-2664.2006.01254.x.

Hagmann, R.K., J.F. Franklin, and K.N. Johnson. 2013. Historical structure and composition of ponderosa pine and mixed-conifer forests in south-central Oregon. Forest Ecology and Management 304: 492-504 https://doi.org/10. 1016/j.foreco.2013.04.005.

Haire, S.L., K. McGarigal, and C. Miller. 2013. Wilderness shapes contemporary fire size distributions across landscapes of the western United States. Ecosphere 4 (1): 15 https://doi.org/10.1890/ES12-00257.1.

Hessburg, P.F., C.L. Miller, S.A. Parks, N.A. Povak, A.H. Taylor, P.E. Higuera, S.J. Prichard, M.P. North, B.M. Collins, M.D. Hurteau, A.J. Larson, C.D. Allen, S.L. Stephens, H. Rivera-Huerta, C.S. Stevens-Rumann, L.D. Daniels, Z. Gedalof, R.W. Gray, V.R. Kane, D.J. Churchill, R.K. Hagmann, T.A. Spies, C.A. Cansler, R.T. Belote, T.T. Veblen, M.A. Battaglia, C. Hoffman, C.N. Skinner, H.D. Safford, and R.B. Salter. 2019. Climate, environment, and disturbance history govern resilience of western North American forests. Frontiers in Ecology and Evolution 7: 1-27 https:/doi.org/10.3389/fevo.2019.00239.

Higgins, A.M., K.M. Waring, and A.E. Thode. 2015. The effects of burn entry and burn severity on ponderosa pine and mixed conifer forests in Grand Canyon National Park. International Journal of Wildland Fire 24 (4): 495-506 https:// doi.org/10.1071/WF13111.

Hjerpe, E., J. Abrams, and D.R. Becker. 2009. Socioeconomic barriers and the role of biomass utilization in southwestern ponderosa pine restoration. Ecological Restoration 27 (2): 169-177 https://doi.org/10.3368/er.27.2.169.

Holden, Z.A., P. Morgan, and J.S. Evans. 2009. A predictive model of burn severity based on 20-year satellite-inferred burn severity data in a large southwestern US wilderness area. Forest Ecology and Management 258 (11): 2399-2406 https://doi.org/10.1016/j.foreco.2009.08.017.

Holden, Z.A., P. Morgan, M.G. Rollins, and K. Kavanagh. 2007. Effects of multiple wildland fires on ponderosa pine stand structure in two southwestern wilderness areas, USA. Fire Ecology 3 (2): 18-33 https://doi.org/10.4996/ fireecology.0302018.

Holden, Z.A., P. Morgan, M.G. Rollins, and R.G. Wright. 2006. Ponderosa pine snag densities following multiple fires in the Gila Wilderness, New Mexico. Forest Ecology and Management 221 (1-3): 140-146 https://doi.org/10.1016/j.foreco.2005.09.014.

Hopkins, T., A.J. Larson, and R.T. Belote. 2014. Contrasting effects of wildfire and ecological restoration in old-growth western larch forests. Forest Science 60 (5): 1005-1013 https://doi.org/10.5849/forsci.13-088.

Huffman, D.W., J.E. Crouse, A.J. Sánchez Meador, J.D. Springer, and M.T. Stoddard. 2018. Restoration benefits of re-entry with resource objective wildfire on a ponderosa pine landscape in northern Arizona, USA. Forest Ecology and Management 408: 16-24 https://doi.org/10.1016/j.foreco.2017.10.032.

Huffman, D.W., A.J. Sánchez Meador, M.T. Stoddard, J.E. Crouse, and J.P. Roccaforte. 2017. Efficacy of resource objective wildfires for restoration of ponderosa pine (Pinus ponderosa) forests in northern Arizona. Forest Ecology and Management 389: 395-403 https://doi.org/10.1016/j.foreco.2016.12.036.

Hunter, M. 2007. Wildland fires use in southwestern forests: an underutilized management option? Natural Resources Journal 47 (2): 257-266.

Hunter, M.E., J.M. Iniguez, and L.B. Lentile. 2011. Short- and long-term effects on fuels, forest structure, and wildfire potential from prescribed fire and resource benefit fire in southwestern forests, USA. Fire Ecology 7 (3): 108-121 https:// doi.org/10.4996/fireecology.0703108.

Kane, V.R., J.A. Lutz, S.L. Roberts, D.F. Smith, R.J. McGaughey, N.A. Povak, and M.L. Brooks. 2013. Landscape-scale effects of fire severity on mixedconifer and red fir forest structure in Yosemite National Park. Forest Ecology and Management 287: 17-31 https://doi.org/10.1016/j.foreco.2012. 08.044 .

Keeling, E.G., A. Sala, and T.H. DeLuca. 2006. Effects of fire exclusion on forest structure and composition in unlogged ponderosa pine/Douglas-fir forests. Forest Ecology and Management 237 (1-3): 418-428 https://doi.org/10.1016/j. foreco.2006.09.064.

Kolb, T.E., J.K. Agee, P.Z. Fulé, N.G. McDowell, K. Pearson, A. Sala, and R.H. Waring. 2007. Perpetuating old ponderosa pine. Forest Ecology and Management 249 (3): 141-157 https://doi.org/10.1016/j.foreco.2007.06.002.

Kuenzi, A.M., P.Z. Fulé, and C. Hull Sieg. 2008. Effects of fire severity and pre-fire stand treatment on plant community recovery after a large wildfire. Forest Ecology and Management 255 (3-4): 855-865 https://doi.org/10.1016/j.foreco. 2007.10.001.

Landres, P.B., P. Morgan, and FJ. Swanson. 1999. Overview of the use of natural variability concepts in managing ecological systems. Ecological Applications 9 (4): 1179-1188 https://doi.org/10.1890/1051-0761(1999)009[1179:OOTUON]2.0.CO;2.

Larson, A.J., R.T. Belote, C.A. Cansler, S.A. Parks, and M.S. Dietz. 2013. Latent resilience in ponderosa pine forest: effects of resumed frequent fire. Ecological Applications 23 (6): 1243-1249 https://doi.org/10.1890/13-0066.1.

Laughlin, D.C., J.D. Bakker, M.T. Stoddard, M.L. Daniels, J.D. Springer, C.N. Gildar, A.M. Green, and W.W. Covington. 2004. Toward reference conditions: wildfire effects on flora in an old-growth ponderosa pine forest. Forest Ecology and Management 199 (1): 137-152 https://doi.org/10.1016/j. foreco.2004.05.034.

Laughlin, D.C., and P.Z. Fulé. 2008. Wildland fire effects on understory plant communities in two fire-prone forests. Canadian Journal of Forestry 38 (1): 133-142 https://doi.org/10.1139/X07-118.

Laughlin, D.C., R.T. Strahan, M.M. Moore, P.Z. Fulé, D.W. Huffman, and W.W. Covington. 2017. The hierarchy of predictability in ecological restoration: are vegetation structure and functional diversity more predictable than 
community composition? Journal of Applied Ecology 54 (4): 1058-1069 https://doi.org/10.1111/1365-2664.12935.

Mclver, J.D., S.L. Stephens, J.K. Agee, J. Barbour, R.E.J. Boerner, C.B. Edminster, K.L. Erickson, K.L. Farris, C.J. Fettig, C.E. Fiedler, S. Haase, S.C. Hart, J.E. Keeley, E.E. Knapp, J.F. Lehmkuhl, JJ. Moghaddas, W. Otrosina, K.W. Outcalt, D.W. Schwilk, C.N. Skinner, T.A. Waldrop, C.P. Weatherspoon, D.A. Yaussy, A. Youngblood, and S. Zack. 2013. Ecological effects of alternative fuel-reduction treatments: highlights of the National Fire and Fire Surrogate study (FFS). International Journal of Wildland Fire 22 (1): 63-82 https://doi.org/10.1071/WF11130.

Merrill, E.H., H.F. Mayland, and J.M. Peek. 1980. Effects of a fall wildfire on herbaceous vegetation on xeric sites in the Selway-Bitterroot Wilderness, Idaho. Journal of Range Management 33 (5): 363-367.

Meyer, M.D. 2015. Forest fire severity patterns of resource objective wildfires in the southern Sierra Nevada. Journal of Forestry 113 (1): 49-56 https://doi.org/ 10.5849/jof.14-084.

Miller, C., and P. Landres. 2004. Exploring information needs for wildland fire and fuels management. In USDA Forest Service General Technical Report RMRS-GTR127. Fort Collins: USDA Forest Service, Rocky Mountain Research Station https://doi.org/10.2737/RMRS-GTR-127.

Miller, J.D., B.M. Collins, J.A. Lutz, S.L. Stephens, J.W. van Wagtendonk, and D.A. Yasuda. 2012. Differences in wildfires among ecoregions and land management agencies in the Sierra Nevada region, California, USA. Ecosphere 3 (9): 80 https://doi.org/10.1890/ES12-00158.1.

Nesmith, J.C.B., A.C. Caprio, A.H. Pfaff, T.W. McGinnis, and J.E. Keeley. 2011. A comparison of effects from prescribed fires and wildfires managed for resource objectives in Sequoia and Kings Canyon National Parks. Forest Ecology and Management 261 (7): 1275-1282 https://doi.org/10.1016/j.foreco. 2011.01.006.

Nicholls, D.L., J.M. Halbrook, M.E. Benedum, H.-S. Han, E.C. Lowell, D.R. Becker, and R.J. Barbour. 2018. Socioeconomic constraints to biomass removal from forest lands for fire risk reduction in the western U.S. Forests 9 (5): 264 https://doi. org/10.3390/f9050264

North, M.P., S.L. Stephens, B.M. Collins, J.K. Agee, G. Aplet, J.F. Franklin, and P.Z. Fulé. 2015. Reform forest fire management - agency incentives undermine policy effectiveness. Science 349 (6254): 1280-1281 https:// doi.org/10.1126/science.aab2356.

Noss, R.F., P. Beier, W.W. Covington, R.E. Grumbine, D.B. Lindermayer, J.W. Prather, F. Schmiegelow, T.D. Sisk, and D.J. Vosick. 2006. Recommendations for integrating restoration ecology and conservation biology in ponderosa pine forests of the southwestern United States. Restoration Ecology 14 (1): 4-10 https://doi.org/10.1111/j.1526-100X.2006.00099.x.

Parks, S.A., C. Miller, C.R. Nelson, and Z.A. Holden. 2014. Previous fires moderate burn severity of subsequent wildland fires in two large western US wilderness areas. Ecosystems 17: 29-42 https://doi.org/10.1007/s10021-0139704-X.

Reynolds, R.T., A.J. Sánchez Meador, J.A. Youtz, T. Nicolet, M.S. Matonis, P.L. Jackson, D.G. DeLorenzo, and A.D. Graves. 2013. Restoring composition and structure in Southwestern frequent-fire forests: a science-based framework for improving ecosystem resiliency. In USDA Forest Service General Technical Report RMRS-GTR310. Fort Collins: USDA Forest Service, Rocky Mountain Research Station https:// doi.org/10.2737/RMRS-GTR-310.

Roberts, S.L., D.A. Kelt, J.W. van Wagtendonk, A.K. Miles, and M.D. Meyer. 2015. Effects of fire on small mammal communities in frequent-fire forests in California. Journal of Mammalogy 96 (1): 107-119 https://doi.org/10.1093/ jmammal/gyu011.

Roccaforte, J.P., A. Sánchez Meador, A.E.M. Waltz, M.L. Gaylord, M.T. Stoddard, and D.W. Huffman. 2018. Delayed tree mortality, bark beetle activity, and regeneration dynamics five years following the Wallow Fire, Arizona, USA: assessing trajectories towards resiliency. Forest Ecology and Management 428 : 20-26 https://doi.org/10.1016/j.foreco.2018.06.012.

Rollins, M.G., T.W. Swetnam, and P. Morgan. 2001. Evaluating a century of fire patterns in two Rocky Mountain wilderness areas using digital fire atlases. Canadian Journal of Forest Research 31 (12): 2107-2123 https://doi.org/10. 1139/x01-141.

Romme, W.H., G.D. Hayward, and C. Regan. 2012. A framework for applying the historical range of variation concept to ecosystem management. Chapter 17 in. In Historical environmental variation in conservation and natural resource management, ed. J.A. Wiens, G.D. Hayward, H.D. Safford, and C.M. Giffen. Hoboken: Wiley-Blackwell https://doi.org/10.1002/9781118329726.ch17.

Sánchez Meador, A., J.D. Springer, D.W. Huffman, M.A. Bowker, and J.E. Crouse. 2017. Soil functional responses to ecological restoration treatments in frequent-fire forests of the western United States: a systematic review. Restoration Ecology 25 (4): 497-508 https://doi.org/10.1111/rec.12535.

Schmidt, L., M.G. Hille, and S.L. Stephens. 2006. Restoring northern Sierra Nevada mixed conifer forest composition and structure with prescribed fires of varying intensities. Fire Ecology 2 (2): 20-33 https://doi.org/10.4996/ fireecology.0202020.

Schoennagel, T., C.R. Nelson, D.M. Theobald, G.C. Carnwath, and T.B. Chapman. 2009. Implementation of the National Fire Plan treatments near the wildland-urban interface in the western United States. Proceedings of the National Academy of Sciences of the United States of America 106 (26): 10706 10711 https://doi.org/10.1073/pnas.0900991106.

Schultz, C.A., T. Jedd, and R.D. Beam. 2012. The Collaborative Forest Landscape Restoration Program: a history and overview of the first projects. Journal of Forestry 110 (7): 381-391 https://doi.org/10.5849/jof.11-082.

Steel, Z.L., M.J. Koontz, and H.D. Safford. 2018. The changing landscape of wildfire: burn pattern trends and implications for California's yellow pine and mixed conifer forests. Landscape Ecology 33 (7): 1159-1176 https://doi.org/10. 1007/s10980-018-0665-5.

Steen-Adams, M.M., S. Charnley, and M.D. Adams. 2017. Historical perspective on the influence of wildfire policy, law, and informal institutions on management and forest resilience in a multiownership, frequent-fire, coupled human and natural system in Oregon. Ecology and Society 22: 23 https://doi.org/10.5751/ES-09399-220323.

Stephens, S.L., B.M. Collins, E. Biber, and P.Z. Fulé. 2016. U.S. federal fire and forest policy: emphasizing resilience in dry forests. Ecosphere 7 (11): e01584 https:// doi.org/10.1002/ecs2.1584.

Strahan, R.T., A.J. Sánchez Meador, D.W. Huffman, and D.C. Laughlin. 2016. Shifts in community-level traits and functional diversity in a mixed conifer forest: a legacy of land-use change. Journal of Applied Ecology 53: 1755-1765 https:// doi.org/10.1111/1365-2664.12737.

van Wagtendonk, J.W. 2007. The history and evolution of wildland fire use. Fire Ecology 3 (2): 3-17 https://doi.org/10.4996/fireecology.0302003.

van Wagtendonk, J.W., K.A. van Wagtendonk, and A.E. Thode. 2012. Factors associated with the severity of intersecting fires in Yosemite National Park, California, USA. Fire Ecology 8 (1): 11-31.

Waltz, A.E.M., M.T. Stoddard, E.L. Kalies, J.D. Springer, D.W. Huffman, and A. Sánchez Meador. 2014. Effectiveness of fuel reduction treatments: assessing metrics of forest resiliency and wildfire severity after the Wallow Fire. Forest Ecology and Management 334: 43-52 https://doi.org/10.1016/j.foreco.2014.08.026.

Whelan, R.J. 1995. The ecology of fire. Cambridge: Cambridge University Press.

White, P.S., and J.L. Walker. 1997. Approximating nature's variation: selecting and using reference information in restoration ecology. Restoration Ecology 5 (4): 338-349 https://doi.org/10.1046/j.1526-100X.1997.00547.x.

\section{Publisher's Note}

Springer Nature remains neutral with regard to jurisdictional claims in published maps and institutional affiliations.

\section{Submit your manuscript to a SpringerOpen ${ }^{\circ}$ journal and benefit from:}

- Convenient online submission

- Rigorous peer review

- Open access: articles freely available online

High visibility within the field

- Retaining the copyright to your article

Submit your next manuscript at $\boldsymbol{\sim}$ springeropen.com 